\title{
The Impact of Different Estrus Synchronization Programs on Postpartum Holstein Dairy Cow Reproductive Performance
}

\author{
Adel Hussien ${ }^{1}$, Heba Sharawy ${ }^{1}$, Yasser Y Lenis ${ }^{2}$, Daniela Jaimes ${ }^{3}$, Ozge Turna ${ }^{4}$, Engy Risha ${ }^{5}$, Wael Eldomany ${ }^{1}$, \\ Samy Zaabel ${ }^{1}$, Mohammed Elmetwally ${ }^{1 *}$ \\ ${ }^{1}$ Department of Theriogenology, Faculty of veterinary medicine, Mansoura University, Mansoura 35516, Egypt \\ 2Departamento de Ciencia Animal, Facultad de Ciencias Agropecuarias, Universidad Nacional de Colombia, Palmira, Colombia \\ ${ }^{3}$ Faculty of Agricultural Sciences, University of Applied and Environmental Sciences U.D.C.A. Bogota, Colombia ${ }^{3}$ \\ ${ }^{4}$ Department of Obstetrics and Gynecology, Faculty of Veterinary Medicine, Istanbul University-Cerrahpasa, Istanbul, Turkey \\ ${ }^{5}$ Department of Clinical pathology, Faculty of veterinary medicine, Mansoura University, Mansoura 35516, Egypt
}

\section{ARTICLE HISTORY}

Received: 26.09 .2021

Revised: 04.10.2021

Accepted: 04.10.2021

Correspondence to: Mohammed Elmetwally; Tel. +201068999571, E-mail: mmetwally@mans.edu.eg

\section{ABSTRACT}

\begin{abstract}
Objective: The purpose of this study was to see how the Ovsynch, modified Ovsynch, presynch, and modified presynch protocols affected postpartum reproductive performance in dairy cows.

Design: Randomized controlled experimental study

Animals: The current research involved 412 dairy cows.

Procedures: The cows were split into four groups: GnRH was given on day 0, PGF2 $\propto$ on day 7, and GnRH on day 9. Group 1: (Ovsynch protocol, $n=117$ ) received $\mathrm{GnRH}$ on day 0 and PGF $2 \propto$ on day 7. Group 2 (modified Ovsynch, $n=113$ ): PMSG on day 0, PGF2 on day 7, and PMSG on day 9. Group 3 (presynch protocol, $n=98$ ) got two doses of PGF2 14 days apart, which allowed for a 12-day delay in the start of Ovsynch. Group 4 (modified presynch protocol, $n=84$ ) got two PGF $2 \propto$ doses 14 days apart, which was 12 days before the start of modified Ovsynch. All of the animals were artificially inseminated 16 hours following their last GnRH or PMSG dose. The ovarian rebound, number of services per conception, days open, and calving interval were the measures for determining reproductive performance for the dairy cows.

Results: The main effect of the synchronisation program showed no significance for ovarian rebound ( $P$ $>0.05)$. The $S / C$, days open and calving intervals were decreased significantly $(P<0.05)$ in the 3rd and 4th groups when compared with the cows that received either GPG or PMSG treatment only. All four groups had a conception rate of $35.04(41 / 117), 40.7(46 / 113), 44.8(44 / 98)$, and $57.14(48 / 84) \%$, respectively $(P<0.05)$. Conclusion and clinical relevance: It was investigated that giving two PGF2 injections before Ovsynch, either utilizing GnRH or PMSG methods, improved the reproductive performance of dairy cows. Furthermore, cows given PMSG had a greater conception rate than cows given GnRH.
\end{abstract}

Keyword: Ovsynch, Presynch, PMSG, synchronization.

\section{INTRODUCTION}

Farmers waste a lot of time using the traditional way of observing cows for heat detection [1]. Many factors, such as milk output, an uneven feed ratio, stress, welfare, and postpartum infections influenced the length and indications of estrus in cows [2-5]. Hormonal treatments have been used in reproductive management to improve estrus identification and save farmers time [6,7]. For almost 30 years, farmers have had access to reproductive control methods like estrus synchronization, ovulation synchronization, and artificial intelligence (AI) [8]. FSH promotes follicle maturation, whereas LH transforms ovarian tissues at the time of ovulation into CL. During the follicular, estrus, and luteal phases of the cycle, the combination of hormone secretion and metabolism maintains the correct hormonal balance $[9,10]$. A combined regimen of GnRH on day 0 , PGF2 on day 7, and GnRH on day 9, followed by single fixed-time insemination, has been shown to result in normal fertility. The first injection of $\mathrm{GnRH}$ is given at a random stage of the cycle and, in the majority of animals, causes ovulation or luteinization of a dominant follicle, if present. The rationale for administering $\mathrm{GnRH}$ again two days after PGF2 is to advance the time of the LH surge and, as a result, advance and synchronize ovulation, so that single insemination is sufficient to ensure normal fertility [6,11-14].

Because of its cost-effectiveness, pregnant mare serum gonadotrophin (PMSG) is commonly utilized for estrus synchronization programs in small and large ruminants [15] [16]. PMSG has mostly FSH-like activity, but it also has some LH-like activity, and it induces follicular development and ovulation in cattle when given intravenously [17]. On day 14 postpartum, PMSG treatment improves follicular development and plasma estradiol levels in cattle without influencing 
subsequent reproductive function $[18,19]$. PMSG is used to either increase the number of small follicles or triggers ovulation in large follicles on the ovaries, followed by PGF2 to reduce corpus luteum growth [20].

The detection of estrus is the most critical aspect affecting the reproductive success of artificial insemination programs, because peak estrus activity generally occurs at night, and determining the real commencement of standing estrus without 24 hours observation might be challenging [21]. At least two times per day, early in the morning and late in the evening, are required for optimal heat detection [22]. Induction of ovulation in heifers and cows with cyclic ovarian function utilizing prostaglandins or their analogs via luteolysis; ovulation will occur 2-5 days after treatment; effective observation of cyclicity and detection will power the conception rate [23] [24]. The goal of this study was to see how different combinations of GnRH, PMSG, and PGF2 affected the rate of conception in postpartum dairy cows.

\section{MATERIALS AND METHODS}

\subsection{Hormones}

Cloprostenol is a synthetic PGF2 that is commercially available (Synchromate; Bremer Pharma B.V., Germany). For intramuscular shots in the form of a sterile, clear, colorless aqueous solution (Cloprostenol $0.250 \mathrm{mg} / \mathrm{ml}$ equal to 0.263 $\mathrm{mg} / \mathrm{ml}$ cloprostenol sodium). Gonadorelin (GnRH) diacetate tetrahydrate (Cystorelin ; Ceva Santé animale, 10 av. De la Ballastière, 33500 Libourne, France) is a GnRH synthetic analouge. Parenterally administered in a sterile aqueous solution (Gonadorelin (GnRH) diacetate tetrahydrate 50 $\mathrm{mcg} / \mathrm{mL}$ ). PMSG (freeze-dried serum gonadotropin, $500 \mathrm{IU}$ ) (Gonaser, Laboratorios Hipra, S.A. Avda. la Selva, 135. 17170 Amer, Girona, Spain).

\subsection{Experimental Design}

The present study was carried out on a dairy farm in Gamesa, Dakahlia governorate. A total of 412 cyclic Holstein dairy cows weighing 450-550 $\mathrm{kg}$ and in good health (Body condition score of 3-3.5 according to [25] were chosen for this study.

Animal cyclicity is based on dairy farm records. After rectal palpation, transrectal ultrasonography (TRUS) was performed (Figure 2). The ultrasound image in left pannel indicates the follicular dynemics at first shot of either $\mathrm{GnRH}$ and PMSG and that in the write pannel indicated ovary at either second GnRH or PMSG. The ultrasound exams were conducted using a real-time B-mode ultrasound scanner (Sonoscape A5, Sonoscape Medical Corp., Guangdong, China) with an $8.0 \mathrm{MHz}$ transrectal linear array transducer to rule out any uterine infection, peri-parturient diseases, calving difficulties, and other reproductive issues. Feeding regimes were maintained throughout the experiment following NRC recommendations (2001). All of the cows in the study were subjected to involuntary waiting periods.

The cows in the experiment were divided into four groups, the cows for each one that was selected randomly: Group 1: a control group ( $n=117)$ that received $100 \mathrm{~g} \mathrm{GnRH}$ shot $\mathrm{I} / \mathrm{M}, 500 \mathrm{~g}$ Cloprostenol administered I/M on day 7 , and $100 \mathrm{~g}$ GnRH injected I/M on day 9. Group 2 ( $n=113)$ : received 500 IU PMSG shots $\mathrm{I} / \mathrm{M}$ at day 0 , followed by $500 \mathrm{~g}$ Cloprostenol injected I/M at day 7, and then 500 IU PMSG shots on day 9. Group $3(n=98)$. At day 0; 500 g Cloprostenol injected I/M, at day 14; $500 \mathrm{~g}$ Cloprostenol injected I/M, at day 26; $100 \mathrm{~g}$ GnRH injected I/M, at day 33; $500 \mathrm{~g}$ Cloprostenol injected I/M, and at day 35; $100 \mathrm{~g}$ GnRH injected I/M. Group 4 $(n=84)$ : Twenty cows were given $500 \mathrm{~g}$ Cloprostenol injected $\mathrm{I} / \mathrm{M}$ on day $0,500 \mathrm{~g}$ Cloprostenol injected I/M on day 14, $100 \mathrm{~g}$ PMSG injected I/M on day 26, $500 \mathrm{~g}$ Cloprostenol injected I/M on day 33 , and $100 \mathrm{~g}$ PMSG injected I/M on day 35 (see figure

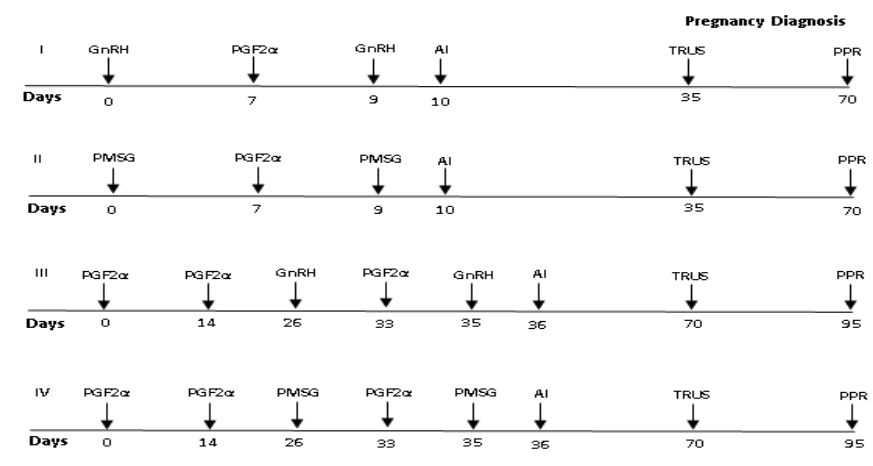

1).

Figure 1. Experimental design for the current study
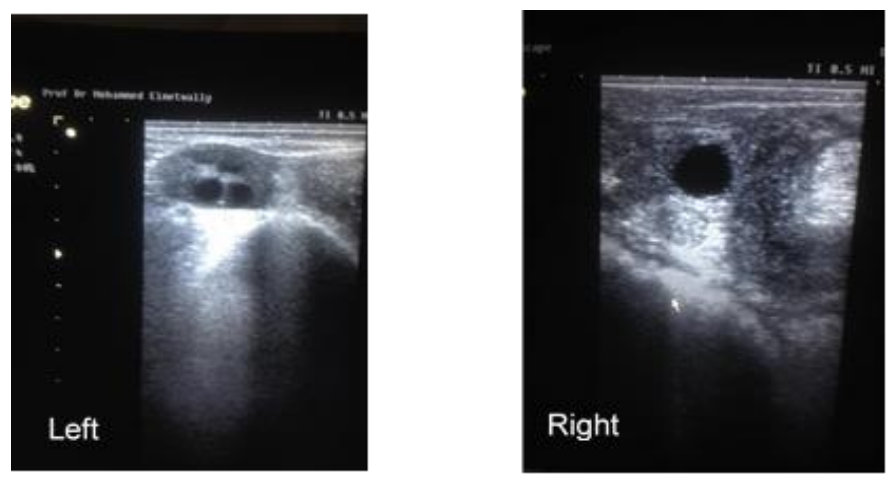

Figure 2. left panel: follicular dynemics in ovaries at first $\mathrm{GnRH}$ or PMSG. Right panel: dominant follicle at time of second GnRH or PMSG

\subsection{Statistical Analysis}

Normality of quantitative parameters (conception rate and the number of services per conception) was assessed using normal probability plots and the Kolmogorov-Smirnov 
test generated with the UNIVARIATE procedure of SAS according to [26-29]. All data are reported as means \pm SEM. Statistical analyses were done using SAS $^{\circledR}$ (version 9.2, SAS Institute, Cary, NC, USA). For all analyses, $\mathrm{P} \leq 0.05$ was defined as significant.

\section{RESULTS}

In this study, as shown in table 1 , there was no significant difference in an ovarian rebound following parturition between all treated cows in different groups $(P>0.05)$. For either gonadotropin and pregnant mare serum gonadotropin. The number of $S / C$ was $(1.27 \pm 0.13)$ and $(1.42 \pm 0.23)$ in the presynch GPG and PMSG meanwhile, it was $(1.5 \pm 0.27$ and $1.58 \pm 0.26)$ for GPG and PMSG treated cows respectively (table 1).

The highest conception rate (57.14) was investigated in the presynch group followed by the PMSG synchronization program when compared to other synchronization programs (35.04; 40.7; 44.8 for GPG; PMSG and presynch GPG treatments respectively, $(P<0.05)$. The days open were long in GPG (3167.35 \pm 56.29$)$ when compared to PMSG (158.92 \pm 47.36); presynch GPG (117.43 \pm 33.09$)$ and presynch PMSG $(113 \pm 25.94, P<0.05$, table 1$)$. In the same manner, there was a significant decrease $(P<0.05)$ in the calving interval in both presynch groups $(363.5 \pm 44.17 ; 359.92 \pm 37.36$ respectively) when compared to the GPG and PMSG treated cows $(341.08 \pm 27.63 ; 336.73 \pm 20.55$ respectively, table 1$)$.

Table 1. The reproductive performances in dairy cows exposed to different synchronization programs

\begin{tabular}{|c|c|c|c|c|c|c|}
\hline Groups & $n$ & $\begin{array}{l}\text { Ovarian } \\
\text { rebound }\end{array}$ & $\begin{array}{l}\text { No of } \\
S / C\end{array}$ & $\begin{array}{l}\text { Conce- } \\
\text { ption } \\
\text { rate }\end{array}$ & $\begin{array}{l}\text { Days } \\
\text { open }\end{array}$ & $\begin{array}{l}\text { Calving } \\
\text { interval }\end{array}$ \\
\hline \multirow[t]{2}{*}{ GPG } & 117 & $62.45 \pm$ & $1.5 \pm$ & $35.04^{c}$ & $167.35^{\mathrm{a}}$ & $363.5 \pm$ \\
\hline & & $9.47^{a}$ & $0.27^{b}$ & & & $6.07^{a}$ \\
\hline \multirow[t]{2}{*}{ PMSG } & 113 & $51.34 \pm$ & $1.58 \pm$ & $40.7^{b c}$ & $158.92^{\mathrm{a}}$ & $364.92 \pm$ \\
\hline & & $14.47^{b}$ & $0.26^{b}$ & & & $17.06^{\mathrm{a}}$ \\
\hline \multirow[t]{2}{*}{ Pre GPG } & 98 & $60.75 \pm$ & $1.42 \pm$ & $44.8^{b}$ & $117.43 b^{b}$ & $341.08 \pm$ \\
\hline & & $17.27^{a}$ & $0.23^{a}$ & & & $15.23^{b}$ \\
\hline \multirow{2}{*}{$\begin{array}{l}\text { Pre } \\
\text { PMSG }\end{array}$} & 84 & $67.83 \pm$ & $1.27 \pm$ & $57.14^{\mathrm{a}}$ & $113.00^{\mathrm{b}}$ & $336.73 \pm$ \\
\hline & & $10.11^{\mathrm{a}}$ & $0.13^{\mathrm{a}}$ & & & $20.55^{b}$ \\
\hline
\end{tabular}

GPG (GnRH, Prostaglandin F2 $\alpha$, GnRH); PMSG= Pregnant mare serum gonadotropins. Values with different letters $(a, b)$ are significantly different and $\mathrm{P}<0.05$

\section{Discussion}

Although cows that exhibit heat symptoms without prior exogenous hormonal stimulation have a higher pregnancy rate than cows that have undergone a different estrus synchronization protocol, the time between parturition and the next pregnancy (open days) is significantly longer in their case than in cows that have undergone TAI. In almost all estrus resynchronization programs, prostaglandin $F(P G F)$ and $\mathrm{GnRH}$ analog $(\mathrm{GnRH})$ injections at the appropriate timing and dose are used $[30,31]$. In the current study, we use the PMSG for the first time instead of GnRH in Ovsynch and try to figure out if this would be significant in the improvement of conception rate and reproductive performance in Holstein dairy cows.

Pursely et al. developed the Ovsynch program for the first time in 1995 as a magical program for increasing pregnancy per artificial insemination (P/Al) after synchronization of ovulation [6]. The preliminary findings of previous studies confirmed the possibility of identifying a subgroup of cows with poor fertility after timed artificial insemination (TAI) at the time of Resynch PGF2 injection. The current study used cows that did not have a $\mathrm{CL}$ and/or a $\mathrm{CL} 15 \mathrm{~mm}$ in diameter, or a putative ovarian cyst at the time of examination [32-35]. Our preliminary hypothesis, that enrolling these cows in presynch Ovsynch protocols could improve pregnancy per artificial insemination (P/AI) after TAl. We hypothesize that the management strategy that included the modification of the Ovsynch protocol would shorten the time to pregnancy, and hence improve the postpartum reproductive performance in Holstein dairy cows.

In the current study, the conception rate in the GPG treated cows was about $35 \%$. This result is a little bit different than that from Pursley and his group which found 55,48 , and $11 \%$ according to the interval between administration of PGF2 and second GnRH [6]. The difference in the conception rate between the two studies may be attributed to the environmental condition and source for PGF2 and GnRH.

In dairy cows, the reproductive efficiency is mainly based on the number of services and conception rate $[6,36,37]$. We assumed that the decreasing number of services per conception and increasing the conception rate will improve reproductive performance. Because estrous detection rates in lactating dairy cows are generally low, producers have attempted to increase the service rate by using a time-Al after two PGF $2 \propto$ injections. The main disadvantage with this approach is the lower conception rate in animals that are exposed to time-Al and synchronized by PGF2 due to variability in time from Al to ovulation.

In the current study, the use of either GnRH and/or PMSG decreases the number of services per conception and increases the pregnancy rate. These results according to the previous studies may be attributed to synchronization of the 
ovulation in most of the experimental animals when compared to either GPG or PMSG/PGF2/PMSG alone.

The ovsynch protocol with GnRH had a $35 \%$ conception rate in the current study. This result is in agreement with the previous findings [38], [39], [40], [41], [42], [43] that found a conception rate around our percentage 33\%, 39\%, 35\%, $38.5 \%, 31.5 \%, 34.9 \%$ respectively. On the other hand, others observed higher conception rates $(48.9 \%, 44 \%, 47.7$ to $53 \%)$, $49 \%$ respectively) [44], [6],[45], and [46]. However, [44], [42], [47], [48] found lower conception rates $25 \%, 25 \%, 27 \%, 23 \%$ respectively. The differences in conception rates seen by various authors with the Ovsynch protocol could be related to differences in responsiveness to the first GnRH injection as well as the animal's cyclicity status at the time of treatment beginning $[7,49]$. This discrepancy in Ovsynch conception rates could be attributed to the fact that the first GnRH may have triggered the growth of a new wave of follicles [50] and [51]

Previous studies used PMSG for improving the pregnancy rate in heifers using norgestomet ear implants [52]. The previous study recorded an increase in pregnancy rates by about $86 \%$ when compared to the cows that did not receive any PMSG (54\%). In GPG estrus synchronization programs, insufficient growth of the dominant follicle causes the onset of a new follicular wave to be delayed, resulting in the absence of a sufficiently sized ovulatory follicle at the time of insemination. Furthermore, research data show that dominant follicles older than 8 days are deemed geriatric and can result in ovulation problems [53]. The use of PMSG was found to increase the diameter of the dominant follicle and subsequently increase the diameter of the resulting $\mathrm{CL}$ and as well the serum progesterone level [54]. According to a previous study, the diameter of the dominant follicle increased in those who were administered PMSG at the time of implant removal, which was linked to PMSG's effect on FSH. These findings may illustrate the improvement of the reproductive performance such as days to the first estrus, days open and calving interval in the cows that received PMSG, and presynch than the cows in the other treated groups. [55] showed that giving two doses of PGF2 14 days apart (presynch) positioned a substantial proportion of cows between days 5 and 12 of the estrus cycle when the ovsynch regimen was started 12 days after the second dose of PGF2.

Because there was no difference in P/TAl and calving interval between Presynch-GNRH and Presynch-PMSG, both regimens were equally successful in enhancing the fertility and improving the reproductive performance of dairy cows. Similar to the results of the current study Giordano et al. 2016 [35] found that the P/TAl was increased with resynch-Osynch of cows that improved the fertility of cows without a $\mathrm{CL} \geq 15 \mathrm{~mm}$. The improvement in reproductive performance for cows engaged in the experimental treatments is largely due to the high overall responsiveness to the presynch procedures. Pre-
Ovsynch procedures' presynchronizing GnRH/PMSG injections induced a robust ovulatory response in the experimental cows. PreG-Ovsynch and PrePMSG-Ovsynch cows must ovulate to the presynchronizing GnRH/PMSG to increase the proportion of cows with a functional $\mathrm{CL}$ at the commencement of the Ovsynch procedure.

In conclusion, the reproductive performances in the presynch ovsynch were determined based on the obtained results using $\mathrm{GnRH}$ and/or PMSG. Because the proportion of follicles ovulating in response to the first GnRH/PMSG injection and the synchronicity of ovulation following the second GnRH/PMSG injection may affect the pregnancy rate, the estrus stage at the time of the first GnRH injection in the Ovsynch protocol is very important. Premature estrus is caused by premature follicular maturity before 2nd GnRH, ovulation before TAl, and the inability of 1st GnRH/PMSG to flip over the dominant follicle late in the estrous cycle.

\section{Acknowledgment}

My gratitude to the coworkers at Safi Masr dairy farm, Gamesa, Dakahlia governorate.

\section{Conflict of interest}

Authors declare that they have no conflict of interest Credit Author Statement

\section{Authors' contribution}

Adel Hussien: Methodology, data collection, hormones infusion, writing, Heba Sharawy: writing and referencing curation; Yasser Lenis: data analysis, writing; Daniela Jaimes: data analysis, writing, Ozge Turna: manuscript curation, writing, and editing; Engy Reisha: manuscript writing and editing; Wael Eldomany: Methodology and writing, Supervision, Samy Zaabel: Methodology and writing, Supervision, Mohammed Elmetwally: Conceptualization, Methodology, Data curation, Writing, Editing, Revision, and Supervision.

\section{REFERENCES}

[1] Firk, R., Stamer, E., Junge, W. and Krieter, J. (2002) Automation of oestrus detection in dairy cows: a review. Livestock Production Science 75, 219-232. https://doi.org/10.1016/S0301-6226(01)00323-2

[2] Lopez, H., Satter, L.D. and Wiltbank, M.C. (2004) Relationship between level of milk production and estrous behavior of lactating dairy cows. Anim. Reprod. Sci. 81, 209-223. https://doi.org/10.1016/j.anireprosci.2003.10.009

[3] Wiltbank, M., Lopez, H., Sartori, R., Sangsritavong, S. and Gümen, A. (2006) Changes in reproductive physiology of lactating dairy cows due to elevated steroid metabolism. Theriogenology 65, 17-29. https://doi.org/10.1016/j.theriogenology.2005.10.003

[4] Gohar, M.A., Elmetwally, M.A., Montaser, A. and Zaabel, 
S.M. (2018) Effect of Oxytetracycline Treatment on Postpartum Reproductive Performance in Dairy BuffaloCows with Retained Placenta in Egypt. JVHC 1, 45-53. https://doi.org/10.14302/issn.2575-1212.jvhc-18-2146

[5] Elmetwally, M.A. (2018) Uterine involution and ovarian activity in postpartum holstein dairy cows. A review. JVHC 1, 29-40. https://doi.org/10.14302/issn.2575-1212.jvhc$18-2447$

[6] Pursley, J.R., Mee, M.O. and Wiltbank, M.C. (1995) Synchronization of ovulation in dairy cows using PGF2 $\alpha$ and GnRH. Theriogenology 44, 915-923. https://doi.org/10.1016/0093-691X(95)00279-H

[7] Thatcher, W.W., Moreira, F., Pancarci, S.M., Bartolome, J.A. and Santos, J.E.P. (2002) Strategies to optimize reproductive efficiency by regulation of ovarian function. Domest. Anim. Endocrinol. 23, 243-254. https://doi.org/10.1016/S0739-7240(02)00160-1

[8] Funston, R.N. and Seidel, G.E. (1995) Gonadotropinreleasing hormone increases cleavage rates of bovine oocytes fertilized in vitro. Biol. Reprod. 53, 541-545. https://doi.org/10.1095/biolreprod53.3.541

[9] Hixon, D.L. (1993) Estrous synchronization in lactating cows. Range Beef Cow Symposium .

[10] Smith, M., Perry, G., Atkins, J.A., Jinks, E., Pohler, K. and Patterson, D. (2005) PHYSIOLOGICAL PRINCIPLES UNDERLYING SYNCHRONIZATION OF ESTRUS. undefined .

[11] Atanasov, B., Dovenski, T., Celeska, I. and Stevenson, J.S. (2021) Luteolysis, progesterone, and pregnancy per insemination after modifying the standard 7-day Ovsynch program in Holstein-Friesian and Holstein cows. J. Dairy Sci. 104, 7272-7282. https://doi.org/10.3168/jds.202019922

[12] Cabrera, E.M., Lauber, M.R., Valdes-Arciniega, T., El Azzi, M.S., Martins, J.P.N., Bilby, T.R. and Fricke, P.M. (2021) Replacing the first gonadotropin-releasing hormone treatment in an Ovsynch protocol with human chorionic gonadotropin decreased pregnancies per artificial insemination in lactating dairy cows. J. Dairy Sci. 104, 8290-8300. https://doi.org/10.3168/jds.2021-20274

[13] Stevenson, J.S. and Sauls-Hiesterman, J.A. (2021) Resynchronizing the first eligible estrus in dairy cattle after a prior insemination and fertility of the prior insemination after gonadotropin-releasing hormone and progesterone treatments. Theriogenology 170, 54-66. https://doi.org/10.1016/j.theriogenology.2021.04.016

[14] Randi, F., Kelly, A.K., Parr, M.H., Diskin, M.G., Lively, F., Lonergan, P. and Kenny, D.A. (2021) Effect of ovulation synchronization program and season on pregnancy to timed artificial insemination in suckled beef cows. Theriogenology 172, 223-229. https://doi.org/10.1016/j.theriogenology.2021.06.021

[15] Bartolome, J.A., Wallace, S.P., Sota, R.L. de la and Thatcher, W.W. (2012) The effect of administering equine chorionic gonadotropin (eCG) and human chorionic gonadotropin (hCG) post artificial insemination on fertility of lactating dairy cows. Theriogenology 78, 1110-1116. https://doi.org/10.1016/j.theriogenology.2012.05.006

[16] Carvalho, N.A.T., Soares, J.G., Porto Filho, R.M., Gimenes, L.U., Souza, D.C., Nichi, M., Sales, J.S. and Baruselli, P.S. (2013) Equine chorionic gonadotropin improves the efficacy of a timed artificial insemination protocol in buffalo during the nonbreeding season. Theriogenology 79 , 423-428. https://doi.org/10.1016/j.theriogenology.2012.10.013

[17] Dieleman, S.J. and Bevers, M.M. (1987) Effects of monoclonal antibody against PMSG administered shortly after the preovulatory LH surge on time and number of ovulations in PMSG/PG-treated cows. J. Reprod. Fertil. 81, 533-542. https://doi.org/10.1530/jrf.0.0810533

[18] Souza, A.H., Viechnieski, S., Lima, F.A., Silva, F.F., Araújo, R., Bó, G.A., Wiltbank, M.C. and Baruselli, P.S. (2009) Effects of equine chorionic gonadotropin and type of ovulatory stimulus in a timed-Al protocol on reproductive responses in dairy cows. Theriogenology 72, 10-21. https://doi.org/10.1016/j.theriogenology.2008.12.025

[19] Rostami, B., Niasari-Naslaji, A., Vojgani, M., Nikjou, D., Amanlou, H. and Gerami, A. (2011) Effect of eCG on early resumption of ovarian activity in postpartum dairy cows. Anim. Reprod. Sci. 128, 100-106. https://doi.org/10.1016/j.anireprosci.2011.09.006

[20] Sheldon, I.M. and Dobson, H. (2000) Effect of administration of eCG to postpartum cows on folliculogenesis in the ovary ipsilateral to the previously gravid uterine horn and uterine involution. J. Reprod. Fertil. 119, 157-163. https://doi.org/10.1530/jrf.0.1190157

[21] Aulakh, B.S. (2008) In vivo Sex fixing in Dairy Animals to produce female progenies. Proceedings of the 15th congress of FAVA .

[22] Voelz, B.E., Rocha, L., Scortegagna, F., Stevenson, J.S. and Mendonça, L.G.D. (2018) Response of lactating dairy cows with or without purulent vaginal discharge to gonadotropin-releasing hormone and prostaglandin $\mathrm{F} 2 \alpha$. J. Anim. Sci. 96, 56-65. https://doi.org/10.1093/jas/skx035

[23] Whittier, W.D., Gwazdauskas, F.C. and McGilliard, M.L. (1989) Prostaglandin F2 $\alpha$ usage in a dairy reproduction program for treatment of unobserved estrus, pyometra and ovarian luteal cysts. Theriogenology 32, 693-704. https://doi.org/10.1016/0093-691X(89)90290-2

[24] Gabor, G., Toth, F., Szasz, F., Petro, T. and Gyorkos, I. (2004) Ways of decrease the period between calvings in dairy cows. 2. Cestrus induction and ovulation synchronisation methods. Magyar Allatorvosok Lapja .

[25] Pryce, J.E., Coffey, M.P. and Simm, G. (2001) The relationship between body condition score and reproductive performance. J. Dairy Sci. 84, 1508-1515. https://doi.org/10.3168/jds.S0022-0302(01)70184-1 
[26] Elmetwally, M.A. (2012) Clinical applicability of noninvasive Doppler ultrasonography in small ruminants throughout pregnancy.

[27] Elmetwally, M.A., Elshopakey, G.E., Eldomany, W., Eldesouky, A., Samy, A., Lenis, Y.Y. and Chen, D.-B. (2021) Uterine, vaginal and placental blood flows increase with dynamic changes in serum metabolic parameters and oxidative stress across gestation in buffaloes. Reprod. Domest. Anim. 56, 142-152. https://doi.org/10.1111/rda.13858

[28] Elmetwally, M.A. and Meinecke-Tillmann, S. (2018) Simultaneous umbilical blood flow during normal pregnancy in sheep and goat foetuses using non-invasive colour Doppler ultrasound. Anim. Reprod. 15, 148-155. https://doi.org/10.21451/1984-3143-AR2017-976

[29] Elmetwally, M. A., Halawa, A. A., Lenis, Y. Y., Tang, W., Wu, G., \& Bazer, F. W. (2019). Effects of BPA on expression of apoptotic genes and migration of ovine trophectoderm (oTr1) cells during the peri-implantation period of pregnancy. Reproductive toxicology (Elmsford, N.Y.), 83, 7379. https://doi.org/10.1016/j.reprotox.2018.12.001

[30] Jaśkowski, J.M., Gehrke, M., Herudzińska, M., Jaśkowski, B.M. and Brüssow, K.-P. (2019) Resynchronisation as an element of improving cattle reproduction efficiency. J. Vet. Res. 63, 107-115. https://doi.org/10.2478/jvetres2019-0009

[31] Macmillan, K.L. (2010) Recent advances in the synchronization of estrus and ovulation in dairy cows. J. Reprod. Dev. 56 Suppl, S42-7. https://doi.org/10.1262/jrd.1056S42

[32] Masello, M., Ceglowski, B., Thomas, M.J. and Giordano, J.O. (2020) A reproductive management program aimed at increasing reinsemination of nonpregnant dairy cows at detected estrus resulted in similar reproductive performance to a program that favored timed artificial insemination. J. Dairy Sci. 103, 3719-3729. https://doi.org/10.3168/jds.2019-17585

[33] Tippenhauer, C.M., Plenio, J.L., Madureira, A.M.L., Cerri, R.L.A., Heuwieser, W. and Borchardt, S. (2021) Factors associated with estrous expression and subsequent fertility in lactating dairy cows using automated activity monitoring. J. Dairy Sci. 104, 6267-6282. https://doi.org/10.3168/jds.2020-19578

[34] Bilby, T.R., Bruno, R.G.S., Lager, K.J., Chebel, R.C., Moraes, J.G.N., Fricke, P.M., Lopes, G., Giordano, J.O., Santos, J.E.P., Lima, F.S., Stevenson, J.S. and Pulley, S.L. (2013) Supplemental progesterone and timing of resynchronization on pregnancy outcomes in lactating dairy cows. J. Dairy Sci. 96, 7032-7042. https://doi.org/10.3168/jds.2013-6960

[35] Giordano, J.O., Thomas, M.J., Catucuamba, G., Curler, M.D., Masello, M., Stangaferro, M.L. and Wijma, R. (2016) Reproductive management strategies to improve the fertility of cows with a suboptimal response to resynchronization of ovulation. J. Dairy Sci. 99, 29672978. https://doi.org/10.3168/jds.2015-10223

[36] Lucy, M.C., Stevenson, J.S. and Call, E.P. (1986) Controlling first service and calving interval by prostaglandin F2 alpha, gonadotropin-releasing hormone, and timed insemination. J. Dairy Sci. 69, 2186-2194. https://doi.org/10.3168/jds.S0022-0302(86)80652-X

[37] Archbald, L.F., Tran, T., Massey, R. and Klapstein, E. (1992) Conception rates in dairy cows after timed-insemination and simultaneous treatment with gonadotrophin releasing hormone and/or prostaglandin F2 alpha. Theriogenology 37, 723-731. https://doi.org/10.1016/0093-691X(92)90151-G

[38] Rajamahendran, R. and Thamotharam, M. (1983) Effect of progesterone releasing intravaginal device (PRID) on fertility in the post-partum buffalo cow. Anim. Reprod. Sci. 6, 111-118. https://doi.org/10.1016/03784320(83)90015-5

[39] Peters, M.W. and Pursley, J.R. (2003) Timing of final GnRH of the Ovsynch protocol affects ovulatory follicle size, subsequent luteal function, and fertility in dairy cows. Theriogenology 60, 1197-1204. https://doi.org/10.1016/S0093-691X(03)00120-1

[40] Klindworth, H.P., Hoedemaker, M., Burfeindt, D. and Heilkenbrinker, T. (2001) [Synchronization of ovulation (OVSYNCH) in high-producing dairy cattle herds. I. Fertility parameters, body condition score and plama progesterone contration]. DTW Dtsch Tierarztl Wochenschr 108, 11-19.

[41] Pursley, J.R., Wiltbank, M.C., Stevenson, J.S., Ottobre, J.S., Garverick, H.A. and Anderson, L.L. (1997) Pregnancy rates per artificial insemination for cows and heifers inseminated at a synchronized ovulation or synchronized estrus. J. Dairy Sci. 80, 295-300. https://doi.org/10.3168/jds.S0022-0302(97)75937-X

[42] Bartolome, J.A., Archbald, L.F., Morresey, P., Hernandez, J., Tran, T., Kelbert, D., Long, K., Risco, C.A. and Thatcher, W.W. (2000) Comparison of synchronization of ovulation and induction of estrus as therapeutic strategies for bovine ovarian cysts in the dairy cow. Theriogenology 53, 815-825. https://doi.org/10.1016/S0093-691X(99)002769

[43] Whisnant, C.S., Washburn, S.P. and Farin, P.W. (2000) Current concepts in synchronization of estrus and ovulation of dairy cows. J. Anim. Sci. 77, 1. https://doi.org/10.2527/jas2000.00218812007700ES0042 $x$

[44] Fricke, P.M. and Wiltbank, M.C. (1999) Effect of milk production on the incidence of double ovulation in dairy cows. Theriogenology 52, 1133-1143. https://doi.org/10.1016/S0093-691X(99)00205-8

[45] Lamb, G.C., Stevenson, J.S., Kesler, D.J., Garverick, H.A., Brown, D.R. and Salfen, B.E. (2001) Inclusion of an 
intravaginal progesterone insert plus $\mathrm{GnRH}$ and prostaglandin F2alpha for ovulation control in postpartum suckled beef cows. J. Anim. Sci. 79, 2253-2259. https://doi.org/10.2527/2001.7992253x

[46] Steckler, T.L., Lock, T.F., Mcloy, G.C. and Kesler, D.J. (2003) Efficacy of ovsynch alone (or) in combination with intravaginal progesterone inserts in dairy cows.

[47] Stevenson, J.S., Pursley, J.R., Garverick, H.A., Fricke, P.M., Kesler, D.J., Ottobre, J.S. and Wiltbank, M.C. (2006) Treatment of cycling and noncycling lactating dairy cows with progesterone during Ovsynch. J. Dairy Sci. 89, 25672578.https://doi.org/10.3168/jds.S0022-0302(06)72333-5

[48] Kasimanickam, R., Collins, J.C., Wuenschell, J., Currin, J.C., Hall, J.B. and Whittier, D.W. (2006) Effect of timing of prostaglandin administration, controlled internal drug release removal and gonadotropin releasing hormone administration on pregnancy rate in fixed-time $\mathrm{Al}$ protocols in crossbred Angus cows. Theriogenology 66, 166-172.

https://doi.org/10.1016/j.theriogenology.2005.10.019

[49] Bello, N.M., Steibel, J.P. and Pursley, J.R. (2006) Optimizing ovulation to first $\mathrm{GnRH}$ improved outcomes to each hormonal injection of ovsynch in lactating dairy cows. J. Dairy Sci. 89, 3413-3424. https://doi.org/10.3168/jds.S0022-0302(06)72378-5

[50] Macmillan, K.L. and Thatcher, W.W. (1991) Effects of an agonist of gonadotropin-releasing hormone on ovarian follicles in cattle. Biol. Reprod. 45, 883-889. https://doi.org/10.1095/biolreprod45.6.883

[51] Twagiramungu, H., Guilbault, L.A. and Dufour, J.J. (1995) Synchronization of ovarian follicular waves with a gonadotropin-releasing hormone agonist to increase the precision of estrus in cattle: a review. J. Anim. Sci. 73, 3141-3151. https://doi.org/10.2527/1995.73103141x

[52] Humblot, P., Grimard, B., Ribon, O., Khireddine, B., Dervishi, V., \& Thibier, M. (1996). Sources of variation of post-partum cyclicity, ovulation and pregnancy rates in primiparous Charolais cows treated with norgestomet implants and PMSG. Theriogenology, 46(6), 1085-1096. https://doi.org/10.1016/s0093-691x(96)00273-7

[53] Mihm, M., Baguisi, A., Boland, M.P. and Roche, J.F. (1994) Association between the duration of dominance of the ovulatory follicle and pregnancy rate in beef heifers. $J$. Reprod. Fertil. 102, 123-130. https://doi.org/10.1530/jrf.0.1020123

[54] Sá Filho, M.F., Torres-Júnior, J.R.S., Penteado, L., Gimenes, L.U., Ferreira, R.M., Ayres, H., Castro E Paula, L.A., Sales, J.N.S. and Baruselli, P.S. (2010) Equine chorionic gonadotropin improves the efficacy of a progestin-based fixed-time artificial insemination protocol in Nelore (Bos indicus) heifers. Anim. Reprod. Sci. 118, 182-187. https://doi.org/10.1016/j.anireprosci.2009.10.004

[55] Moreira, F., Sota, R.L. de la, Diaz, T. and Thatcher, W.W. (2000) Effect of day of the estrous cycle at the initiation of a timed artificial insemination protocol on reproductive responses in dairy heifers. J. Anim. Sci. 78, 1568-1576. https://doi.org/10.2527/2000.7861568x 